\title{
ASPEKTI DRUGOSTI U RANOM PUTOPISNOM DISKURSU MILOŠA CRNJANSKOG O BANATSKIM ŠVABAMA U SVETLU POTESTARNE IMAGOLOGIJE ${ }^{1}$
}

$\mathrm{U}$ radu je, s aspekta potestarne imagologije, fokusirana rana putopisna proza Miloša Crnjanskog koja tematizuje problematiku vezanu za život Švaba nastanjenih u Banatu, koji su, nakon Prvog svetskog rata, pripali Kraljevini Srba, Hrvata i Slovenaca. Ratne reperkusije su se na specifičan način reflektovale na njihov poratni život, s obzirom na to da su se, u novom društvenom kontekstu, našle u poziciji unutrašnje Drugosti. Predmet istraživanja je razmotren na osnovu upečatljivog putopisnog svedočenja Crnjanskog (O Banatu $i$ o Banaćanima, te Izveštaji iz Vojvodine, iz 1923-1925). Zapaža se da su Crnjanskove predstave o Švabama građene u vidu imagema na kontrapunktu opozitnog bilateratnog para identitet / alteritet. Stoga su, istovremeno, sagledane i Crnjanskove predstave o sopstvenoj zemlji, njenoj vlasti i narodu. U poziciji identiteta je srpski, a u poziciji alteriteta je nemački (švapski) entitet. Vizura donosi pregled pozitivnih i negativnih karakteristika sa obe strane opozitnog para. S tim u vezi, posebna pažnja je posvećena potestarnim imagologoškim vizurama, s akcentom na komunikativnim aspektima vlasti i njenom odnosu prema švapskoj Drugosti, ali i odnosa Švaba prema toj vlasti, u konkretnom kulturnom kontekstu.

Ključne reči: potestarna imagologija / putopisni izveštaji M. Crnjanskog / banatske Švabe / unutrašnja Drugost /metis.

Sofija M. Košničar, grinja@neobee.net

Rad je zasnovan na istraživanju sprovedenom u okviru projekta Aspekti identiteta i njihovo oblikovanje u srpskoj književnosti (broj 178005) koji se, pod rukovodstvom prof. dr Gorane Raičević, izvodi na Odseku za srpsku književnost Filozofskog fakulteta Univerziteta u Novom Sadu, a uz finansijsku pomoć Ministarstva prosvete, nauke i tehnološkog razvoja Republike Srbije. 


\section{SVAKODNEVICA - TOPOS PUTOPISNE PROZE}

Osnovni predmet pažnje putopisne proze, koja nastaje kao „rezultat realnog putovanja“ fokusiran je na svakodnevicu konkretnog geo-političkog prostora o kojem putopisac svedoči (Lazarević Radak, 2011: 950). Sta je, međutim, označeno sintagmom „svakodnevni život“ umnogome zavisi od teorijske perspektive. Još je Elijas ${ }^{2}$ ukazao na to da različiti autori, koristeći isti termin, zapravo pod njim podrazumevaju čitav spektar različitih značenja. Tako, shvatanje svakodnevice u supstantivnom i egzistencijalnom smislu u duhu oikosa ${ }^{3}$, kako ističe Elijas, može da označava, između ostalog: običan dan nasuprot prazničnom danu; život provođen $u$ teškom radu, nasuprot lagodnom životu od profita ili rente; život širokih slojeva naroda, nasuprot životu elite (od kraljeva i aristokrata, do džet-seta); rutina bez iznenađenja koja se ponavlja iz dana $u$ dan, naspram krupnih istorijskoh događaja (prevrata, ratova, revolucija); privatnost nasuprot javnom, profesionalnom životu. Dakle, konvencionalno određenje svakodnevice ističe da je ona područje običnog, ni po čemu izuzetnog života iz dana u dan, ispunjenog rutinskim i repetititivnim aktivnostima, te je zbog toga dugo bilo ignorisano područje ljudskog bitisanja (up. Spasić, 2012: 74).

Međutim, za razliku od poimanja svakodnevice kao suprotnositi političkom, kao nečeg u biti nepolitičnog i antipolitičnog, kao, dakle, oblasti iz koje je politika „proterana“; ili sagledavanja da je ona mesto političke borbe, prvenstveno otpora okoštalim sistemima, moćnim grupama, i, uopšte, silama dominacije - savremene teorije sagledavaju svakodnevni život kao vrelo iz kojeg ističe etablirana, "vidljiva" politika, koja participira u formiranju identiteta odgovarajuće kulture. Savremeni kritički pristupi svakodnevnom životu ${ }^{4}$ sve su, dakle, skeptičniji prema ideji po kojoj je politika specijalizovana delatnost koja se odvija "negde drugde", u izdvojenim arenama, a da svakodnevni život ostaje po strani, njome nedotaknut. Naprotiv, ,savremena stanovišta ističu da je svakodnevica u potpunosti prožeta odnosima moći, hijerarhije, autoriteta i pobune, te sagledavaju [...] svakodnevni žovot kao teren stalne političke borbe" (Spasić, 2012: 80). Stoga je svakodnevica, kako ističe Bojcov [Михаил Анатольевич Бойцов] jedan od osnovnih domena istraživanja potestarne imagologije ${ }^{5}$. U Crnjanskovim putopisima kojima je ovde

2 Norbert Elijas [Norbert Elias]. Videti njegovu knjigu Proces civilizacije, Sremski Karlovci: IK Z. Stojanovića, 2001. Elijas je upravo tom svojom istorijskom sociologijom doprineo tematizaciji svakodnog života.

3 Antička civilizacija je svet privatnosti i domaćeg, oikos, smatrala inferiornim u odnosu na polis - domen javnog, političkog, značajnog (up. Spasić, 2012: 74).

4 Na primer: Willius Paul (1997). Learning to Labour: How Working Klass Kids Get Working Class Jobs. Aldershot: Gower; Smith Dorothy E. (1987). The Everyday World as Problematic: A Feminist Sociology. Boston: Northeastern University Press

5 Imagologija (od lat. imago - slika, predstava) shvaćena kao naučna oblast interdisciplinarne prirode, koja se bavi izučavanjem zakonitosti stvaranja, funkcionisanja i interpretacije oblika "drugih", "tuđih" stranih onom ko je sa njima u kontaktu (spram: Бойцов, 2010: 8). Potestaran od lat. potestas, -atis $f:$ vlast. Kako ističe Bojcov, predmet pažnje potestarne imagologije su, između ostalog, ,oblici vlasti [...] opštenje u kome se potvrđuje ili osporava legitimnost postojećeg poretka, označuju se njegove željene ili njemu suprotne, neželjene alternative, bojaznost i strah raznih grupa, kako vladajuće elite, tako i potčinjene 
reč́, upravo su fokusirani aspekti upliva vlasti u svakodnevicu banatskih Švaba ${ }^{7}$ (u poziciji unutrašnje Drugosti) koji koreliraju sa „komunikativnim aspektima vlasti“, odnosno „njenim opštenjem u kome se potvrđuje, ili osporava legitimnost postojećeg poretka, označuju se njegove željene ili njemu suprotne, neželjene alternative, bojaznost i strah raznih grupa, kako vladajuće elite, tako i onih potčinjenih većini“ (Бойцов, 2010: 16). S tim u vezi, a vrlo bitno u ovom kontekstu, ukažimo i na sledeće. Kada je u putopisanju, u diskursu svakodnevice, fokus na drušveno-ekonomskim prilikama, političkom i socijalnom događanju, aktuelnim $\mathrm{u}$ vreme nastanka konkretnog putopisnog svedočenja, putopis poprima svojstva reportaže ${ }^{8}$. Čini se da je upravo zbog tog njihovog izrazitijeg reportažnog karaktera, Dejvid Noris ustvrdio da ,putopisi Crnjanskog iz tridesetih godina imaju manju vrednost od onih iz dvadesetih godina“" (Noris, 1993: 14). Imajući, dakle, naznačeno

većine“ (Бойцов, 2010: 16). Ona, takođe, izučava i simbolička sredstva koja imanentno obeležavaju vlast, identifikuju je u odgovarajućem istorijskom diskursu (na pr. zastave, heraldika, krune). Takođe proučava najraznovrsnije simbole vlasti koji se očituju u gestama, ceremonijama, ritualima, predmetima, muzici (njihovom prisustvu ili odsustvu kao što je, na primer, marš, himna, „svečana tišina“). Znaci (simboli) prisustva/odsustva vlasti se mogu očitovati čak i u mirisima (tamjan, drugi miomirisi), vizuelnim i taktilnim osećajima, tkaninama, nakitu, arhitekturi i urbanizmu, a neretko i u odgovarajućoj osmišljenosti prirodnih objekata i okruženja, primerice parkova (Бойцов, 2010: 23). U polju interesovanja potestarne imagologije je i ,geografski i kulturni areal u kome se vlast primenjuje (Бойцов, 2010: 35). Da li je unutar toga areala centar (ili centri) u kome je odgovarajući oblik vlasti „pronađen“ i odakle je potekao? Kakve su okolnosti doprinele njegovom rasprostiranju? Kakve je transformacije doživeo (preosmišljavanje, prilagođavanje, banalizacija i drugo) na periferiji (ili čak na raznim periferijama) (Бойцов, 2010: 39). Da li na periferiji opstojava oblik vlast koji u centru više ne postoji?“ Dakle, oblik vlasti, može da se izgubi u ,centru“ ali da i dalje postoji na ,periferiji“, te se razmatraju pitanja mogućnosti ,,rekonstruisanja iščezlog 'centra' na osnovu očuvanosti oblika vlasti na 'periferiji '“"(Бойцов, 2010: 42; sa ruskog preveo autor ovoga rada).

6 Osnovnu građu za ovo istraživanje čine putopisi Miloša Crnjanskog nastali mahom u periodu 1923-1925, dakle, njegova rana putopisna svedočenja koja se vezuju za period Kraljevine Srba Hrvata i Slovenaca. Objavljeni su u knjizi: O Banatu i o Banaćanima, Novi Sad: Književna zajednica, 1989 (putopisi: Na banatskoj ravnici [objavljeno 1923.] str. 19-25; Temišvar II [1923.] 31-40; Temišvar IV [1923.] 47-52; Žombolj na točkovima [1923.] 54-62; Vršac I [1925.] 91-95; Vršac II [1925.] 96-102; O Dolovu, selu flamanskome [1925.] 113-119; Manastir Mesić [1925.] 105-109; Grobnica Čarnojevića [1923.] 81-87; Selo Kikinda [1923.] 71-75). Putopisi I. Beograd: Zadužbina Miloša Crnjanskog, 253-324, 1995a (Iris Berlina iz 1928); Putopisi II: Beograd: Zadužbina Miloša Crnjanskog, 1995b (poglavlje Izveštaji iz Vojvodine, putopisi: Radikali u Kikindi [1923.] 80-83; U obećanoj zemlji [1923.] 68-72; Švabe i Mađari [1923.] 61-64).

7 O postojbini Švaba videti, na primer u „Podunavske Švabe“. Udruženje Nemaca „Gerhard“. Preuzeto 18. 07. 2015, sa: http://www.gerhardsombor.org/sr/str-10-Podunavske-svabe.html

8 U reportaži su, u žiži pažnje, konkretni, u datom vremenu aktuelni događaji, situacije i stanja u kojima „,buja“ ili „tinja“ ekonomska i/ili politička problematika u određenom kontekstu, odnosno, ,predstavle svakodnevnih političkih razmirica [...] ekonomski usponi i padovi, političke okolnosti kojima je zahvaćena zemlja[...]" (Lazarević Radak, 2011: 949-950). Kao i putopis, reportaža, u imagološkom smislu, donosi manje-više subjektivnu viziju (najčešće iz ugla reportera emocijama „tretiranu” stvarnost). Međutim, dok je za reportažu uvek povod aktuelan društveno-politički, mogućno i dramatični ekonomski, ili kulturni događaj, pojava ili proces (što jeste i u fokusu pažnje reportaže) za putopis to nije karakteristično. I dok, na primer, putopis, kao beletrizovan žanr, može biti putopisna fikcija, u kome je mogućna "subjektivnost" kako piščeve vizure, tako i faktografske datosti, za reportažu je obavezujuća ,istinitostobjektivnost situacije" (nefikcionalnost u smislu faktografske realije), dok je pozicija piščeve vizure fakultativna, odnosno, može biti manje-više objektivna. Primerice, u angloameričkom novinarstvu reportaža donosi priču-izveštaj o aktuelnom događaju, sa mogućim dramatičnim zbivanjima, ali uvek u vidu "suve, precizne, faktografije" uz minimalizaciju subjektivnog doživljaja i stava novinara. Otuda i srodna sintagma putopisni izveštaj (spram Đurić, 1997: 585; Srdić, 1979: 267-268 ). 
u vidu, putopisi Crnjanskog, u kojima je tematizovana problematika Švaba, ali i izvesni njegovi drugi putopisni izveštaji, recimo oni iz Španskog građanskog rata ${ }^{9}$, upravo se mogu sagledati kao hibridni, putopisno-reportažni žanr, čija je faktografija, po definiciji žanra, nefikcionalna i time, sa stanovišta verodostojnosti zbilje, pouzdanija od izvesnih drugih proznih oblika. Upravo je to bitan kvalitet koji ovakvu prozu preporučuje za imagološka istraživanja.

\section{SEMIOTIČKO-KULTUROLOŠKI KONTEKST CRNJANSKOVIH RANIH PUTOPISA}

Izučavanje Drugosti ${ }^{10}$, kao jednog od fundamentalnih imagoloških aspekata, upućuje na, kako ističe Blažina, značaj uvažavanja Fišerovog ${ }^{11}$ mišljenja da bi ,interdisciplinarna imagološka istraživanja trebala uzeti u obzir povjesnost nacionalno-imagotipskih sustava i kontekstualnu ovisnost književnih `slika stvarnih zemalja', kao elemenata složenih međunacionalnih uzajamnih veza“" (Blažina, 2010: 475).

Imajući u vidu istorijski kontekst predmeta ovog istraživanja, podsetimo na to da je nakon Prvog svetskog rata ${ }^{12}$, a prekrajanjem evropskih granica, Kraljevina Srba, Hrvata i Slovenaca nastala kao multikulturno društvo u kome su ,pripadnici različitih kultura živeli jedni pored drugih, ali i jedni s drugima" (Stojković, 1996: 256). U vezi s tim, napomenimo da je u polju ,interesovanja potestarne imagologije, između ostalog, geografski i kulturni areal u kome se vlast primenjuје“ (Бойцов, 2010: 35). Poratne okolnosti u kojima su se dunavske Švabe ${ }^{13}$ nastanjene u Banatu

9 Đukić, Đ. (prir.) (1990). „Iz istorije štampe: Ratne reportaže iz Španije Miloša Crnjanskog“, Novinarstvo 3-4, 89-109. Beograd: Jugoslovemski institut za novinarstvo [trinaest reportaža M. Crnjanskog].

10 Julija Krsteva [Юлия Кръстева] i Žak Lakan [Jacques Marie Émile Lacan] ističu da se Drugi prepoznaje kao uslov celovitosti. Utoliko se celovitost traži u interakciji sa Drugim koji postaje replika prvobitno uočene slike u ogledalu. Tako stranac i drugačijost na kojoj se on kao objekt zasniva postaje privlačna stoga što putnik samo u interakciji sa njim može prepoznati sebe kao entitet, a upoznavanje drugih delova sveta prestaje da se shvata kao odraz puke potrebe za gospodarenjem. Sam čin putovanja shvaćen je kao izraz preplitanja višestrukih faktora, a ovladavanje i gospodarenje, pružaju se ispod ekonomske podloge, jer se okončavaju suptilnim formama dominacije (Lazarević Radak, 2012 web: uvod )

11 Među najpoznatijim predstavnicima Ahenske (Aachen) škole imagološke misli su Hugo Dizerink [Hugo Dyserinck], Manfred Fišer [Manfred S. Fischer], Jozef Teodor Lirsen [Joseph Theodoor "Joep" Leerssen] i Karl Ulrih Zindam [Karl Ulrich Syndam]. Istaknuti predstavnici francuske škole imagološke misli su komparatisti: Daniel-Henri Pažo [Daniel-Henry Pageaux] i Žan-Mark Mura [Jean-Marc Moura] (Blažina 2010: 474).

12 Prvi svetski rat započet telegramskom objavom rata Austrougarske Srbiji 28. jula 1914, u Srbiji je doživljen kao nametnuti rat (spram Šulović, 2014: 16). To se vidi već iz prvog reagovanja Nikole Pašića, Kraljevog ministra inostranih dela, koji je, po prijemu depeše, izjavio:”'To smo i očekivali. Naša je stvar pravedna. Bog će nam pomoći" (Šulović, 2014: 17). U toj ratnoj pošasti Srbija je izgubila milion i sto hiljkada ljudi, a 1.250 .000 njih je bilo ranjeno (Žrtve u Prvom svjetskom ratu. Žrtve po zemljama, 21. 06. 2015, web: tabela). Nemačko carstvo je izgubilo kolonije i proglašeno je odgovornim za rat. Od teritorije koje je zauzimala Austrougarska stvorene su Austrija, Mađarska, Čehoslovačka i Kraljevina Srba, Hrvata i Slovenaca. SHS postoji od 1. 12. 1918. do 3. 10. 1929. Tada menja ime u Kraljevina Jugoslavija.

13 U cilju što jasnijeg razumevanja prirode švapske Drugosti, podsetimo se na to da su dunavske Švabe (nem. Donauschwaben) Nemci koji su od 18. veka živeli u Translajtaniji, istočnom delu Habzburške monarhije. U vreme raspada Austrougarske, područja nastanjena dunavskim Švabama podeljena su između Kraljevine SHS, Rumunije i Mađarske. 
(kao pripadnici nacionalnog entiteta koji je izgubio rat, a pri tome, smatran njegovim inicijatorom i pravim promoterom) našle u kontekstu novoformirane države sa strane pobednka rata - učinile su njihov položaj delikatnim, što se ogleda i u Crnjanskovim putopisima. Sam putopisac veli da, osim što je želeo da ih prikaže u svakodnevici, namera mu je bila, da u poratno vreme ,pokuša da vidi kako odjekuje u njinim dušama užasna beda Nemačke, izumiranje i patnje“ (Crnjanski, 1989: 57-58).

Putopisac je, međutim, neminovno, kreacija kulture u kojoj je oblikovan ${ }^{14}$, te piše na osnovu sopstvene predstave o Drugom. U semiotičko-kulturološkom smislu, putopisac, kao, uostalom, i drugi pripadnici odgovarajuće kulture, formiraju svoju podelu sveta na unutrašnji (naš/moj) i spoljašnji (njihov, tuđ) prostor, a osnovni kriterijum te podele je različitost, Drugost, kao svojevrstan alteritet (Lotman, 1992: 15). Kompatibilno naznačenom, kada je reč o književnom delu, Blažina, a prema mišljenju Žan-Mark Mure, ističe da je ,pojam predodžba skup ideja o stranim zemljama i narodima obuhvaćenih procesom literarizacije, ali i socijalizacije“ te zbog toga ,imagologija [...] mora proučavati društveno imaginarno, koje okružuje književnu sliku o Drugome“" (Blažina, 2010: 478). Blažina veli da Lirsen, stoga, ukazuje na potrebu jedinstvenog pristupa u proučavanju književnih, pa i putopisnih tekstova, „koji bi u obzir uzimao ne samo verbalnu supstancu teksta nego i povijesni kontekst teksta, te ideološki rezonator o koji se on odbija“ (Blažina, 2010: 477). Upravo taj ,ideološki rezonator“ dobrim delom artikulišu dominantni politički subjekti, tačnije država i njena vladajuća politika. S gledišta potestarne imagologije, koja se, u najopštijem smislu, bavi „istraživanjem komunikativnih aspekata vlasti““ (Бойцов, 2010: 8) njenog odnosa prema svim segmentima društva i državne zajednice u celini u konkretnim kulturama - posebno je interesantno razmotriti odnos etablirane vlasti u Kraljevini Srba, Hrvata i Slovenaca prema banatskim Švabama kao Drugosti, ali i odnosa Švaba prema toj državi. Putopisna proza, pa i Crnjanskova, kao prostor susreta i sučeljavanja reprezentacija o mnogobrojnim vidovima ispoljavanja konkretnih kultura pojedinih naroda, te odnosa vlasti prema njima - jeste, dakle, izvanredna građa i za potestarna imagološka izučavanja švapskog pitanja između dva svetska rata. Tim pre, što je za referentnu Crnjanskovu putopisno-reportažnu prozu karakteristična nefikcionalnost i utemeljenost prikaza na faktografiji konkretnih situacija sa putovanja.

Predstava o Drugom neminovno je kulturološki „,zasenčena“. Pri tome, zbog delovanja i ,psiholoških faktora u vezi sa strepnjom od tuđeg, drugog, nepoznatog, osnova svakog putopisa ostaje imaginarna", a "inficiranost elementima 'tuđeg' mahom se ,prerađuje', prevodi u, za konkretnu kulturu, prihvatljiv modalitet, manje tuđ i manje Drugi, kao da prolazi svojevrsnu kulturološku imunizaciju" (Lazarević Radak, 2011: 949-950). Pisanje iz „zasenčenja“ sopstvenom kulturom,

14 Jasno je da putopisac, kao i svaka druga ljudska individua, može biti kulturološki oblikovan sinergijskim delovanjem više kultura (u višenacionalnim porodicama, življenjem u različitim kulturama...). 
o „tuđem“ često je opterećeno kulturološkom boljkom tipa predrasuda i stereotipa ${ }^{15}$, a ta boljka nastaje kao „rezultat nikakve, ili nedovoljno uspešne imunizacije elementima tuđeg“" (Lazarević Radak, 2011: 950). Stereotip se, dakle, slikovito može odrediti kao "mamac preovlađujućeg shvatanja" koji se formira putem "uspostavljena modela uopštavanja“ zasnovanog na "redukciji”" (spram Đerić, 2005a: 105). Redukcija, pak, potiče iz "čovekove nužnosti da sažima i pojednostavljuje utiske i predstave o svetu, odnosno u njegovoj potrebi sažetog definisanja", te da mu je bitna funkcija "izgradnja specifičnih svojstava 'etnotipa", odnosno pokazivanje dispozitiva savremenih priča o "kolektivnom imidžu” (Đerić, 2005a: 106).

Međutim, u putopisnim izveštajima Crnjanskog, preovlađujuće viđenje banatskih Švaba, kao unutrašnje Drugosti, nije stereotipno. To nije slučajno, jer je ono utemeljeno u dobrom poznavanju švapskog mentaliteta iz lične, konkretne životne prakse. Crnjanski je godinama živeo u njihovom neposrednom okruženju. Rođen u Čongradu pod habzburškom krunom, Crnjanski je, kao dete i mladić oblikovan u toj građanskoj kulturi suživota s temišvarskim Mađarima i Nemcima. Od najmlađih dana je obrazovan u odličnim školama, učeći i družeći se s mađarskim i nemačkim plemstvom u Temišvaru, potom u Rijeci i Beču; naučen da, poštuje „svoje“, a ,imuniziran“ Drugošću barem do mere kurtoazne građanske tolerancije ${ }^{16}$. Dakle, Crnjanski je Švabe upoznavao tokom dugog vremenskog perioda, direktno i neposredno, kroz konkterne situacije, a ne na načine koji dovode do formiranja stereotipa. Upravo Leerssen ističe da je priroda

stereotipa i predrasuda takva da se ne možemo prisjetiti gdje smo ih točno naučili. Uklopljeni su u našu kulturu pismenosti u ranom neformalnom stadiju procesa socijalizacije, u ranom djetinjstvu, kao dio tekstova koji su po sebi kratkoga daha i nepamtljivi (vicevi, stripovi, filmovi B-produkcije,

15 Stereotip nema jednoznačan karakter, pa se njegovo definisanje u društvenoj teoriji pokazuje kao složen zadatak. Jedno od prvobitnih određenja stereotipa svakako je "slika u našim glavama” (Đerić, 2005a: 106). Smatra se da je stereotip lažna predstava budući da je zasnovana na minimumu znanja o onome što je predmet tipizacije te se u teorijskom promišljanju kvalifikuje kao odsustvo stava. Njegove bitne odlike su načelna selektivnosti (u smislu nužnosti redukcije) i selektivnost informacija (u smislu nedovoljnog poznavanja). Karakteristika da mu je zajednički imenitelj objedinjavanje redukovanog i pojednostavljenog znanja o fenomenu u svojevrsnu njegovu "sliku u našim glavama" stereotip je važan sadržaj imagoloških izučavanja. Vezuje se prvenstveno za zbirno predstavljanje (spram Đerić, 2005a: 105). Stereotip je kognitivna funkcija tipizacije (šablonizacije, katalogizacije i sl.) i predstavlja izraz nužnosti jezičkog $i$ misaonog ekonomisanja. S obzirom na to da je kontekstualne prirode stereotip kao „tipski model” koji daje opisu "savremenog stanja" fenomena u aktuelnom vremenskog kontekstu" često koketira s onim što je “društveno poželjno ili politički korektno" (Đerić, 2005a: 107). Može biti upotrebljen kao sredstvo usmeravanja "kompleksnijih projekata", odnosno u funkciji strukturisanja, održavanja ili (pre)osmišljavanja "slike sveta" (Đerić, 2005b: 41-46).

16 „Moj krug je bio krug mojih, katoličkih, drugova, plemića i njihovih namirisanih sestara, sa kojima sam uzimao časove francuskog jezika“ jer se u školi redovno učio nemački i mađarski (Crnjanski, 1989: 35). „Od mojih drugova ostala su mi samo imena. Kalinfalvi Jurka Đula, Kapdebo Elemer Đika. Gde su, i da li su živi, ne znam. Prvi mi se poslednji put javio pre Prvog svetskog rata, sa Eksportne akademije u Kelnu [...] Pored tog Temišvara mađarskih plemića [...] postojao je i jedan drugi [...] Temišvar Srba, ostatak ostatka, varoš stara, umiruća, fanatična verska diaspora, kao i Temišvar Jevreja“ (Crnjanski, 1989: 36-37). 
poslovice ili frazemi, promidžbeni plakati, ili televizijske emisije). Sheme koje preživljuju u našoj svijesti kao ostatak svih tih malih, pojedinačno beznačajnih iskustava kulturne socijalizacije, rezultiraju predrasudom i stereotipom (Leerssen, 2009: 116-117).

U kontekstu citiranog, zapazimo da je, dakle, mahom reč o medijski posredovanim iskustvima. Međutim, tekstura medijski posredovana, neminovno je samo već nečiji izbor „,redukcija“ i mentalna obrada, odnosno, kulturološki je već „,zasenčena“. Upravo je, dakle, zbog toga, istraživanje Crnjanskovih naznačenih putopisa, kulturološki značajno, jer se može očekivato izvesna njihova manja zasenčenost stereotipijom i predrasudama. Tim pre, ako imamo u vidu Lirsenovo zapažanje da je „nacionalna stereotipizacija slobodnija pod onim što je Mann nazvao [...] krinkom 'fiktivnih konvencija u kontekstu narativnih karakterizacija', nego u nefiktivnoj referentnoj prozi“" (Leerssen, 2009: 112-113). S tim u vezi, on upućuje i na Spieringov nalaz da ,fikcionalni tekstovi dopuštaju drastičnije tvrdnje nego nefikcionalni“" (Leerssen, 2009: 113). I samom Crnjanskom je dobro poznato da su stereotipi kulturološke zamke, kojih se treba čuvati, ako se teži objektivnosti, pa zapaža da ,pri izlasku iz berlinske stanice, stranac sa sobom unosi u tu varoš i svoj veliki prtljag predrasuda“" (Crnjanski, 1995b : 269). Zbog toga nastoji da o švapskoj Drugosti zaključuje na osnovu posmatranja, realnih činjenica i neposrednog svedočenja tih Drugih. Imajući u vidu rečeno, pre bi se, dakle, moglo ustvrditi da prestave o Švabama kod Crnjanskog nisu stereotipne, već da se tu radi o onome za šta, naglašava Blažina, Pažo veli da je ,društveno imaginarno obilježeno bipolarnošću identitet / alteritet" (Blažina, 2010: 477) te da bi se u slučaju Crnjanskovog viđenja Švaba kao unutrašnje Drugosti, umesto stereotipa, pre moglo govoriti o „,nacionalnom imagemu (otisak)“ - Pažoovom nazivu za „ambivalentni binarni polaritet opozicijskih parova (primjerice Sever-Jug, jak-slab, središnji-periferni) zbog kojega se svaka nacija prikazuje kao nacija kontrasta“" $u$ odnosu na drugu (Blažina, 2010: 477). Međutim, iako, u retoričkom smislu, modelovane u kontrastima - te predstave ne moraju, nužno, biti stereotipi. Kod Crnjanskog i nisu. Kako zapaža Blažina, u vezi s tim, Lirsen smatra da je „,polazna pretpostavka kontakta s različitim kulturama etnocentrizam, dok je svako odstupanje Drugost" (Blažina, 2010: 478). To je mišljenje kompatibilno Lotmanovom viđenju semiotičkog kulturološkog polariteta naš / njihov, na kome se izgrađuje kulturni alteritet i u kome dijakritičko polje alteriteta ima bitno uporište u nacionalnom identitetu. U ovom slučaju, moglo bi se govoriti o etnocentričnom uporištu i kontrastiranju većinskog, srpskog entiteta, koji je konstituisao vlast u Kraljevini SHS, i o opozicionom švapskom etnosu u poziciji Drugosti. Međutim, iako svoje viđenje pomenutog bilaterarnog odnosa Crnjanski, pre svega u retoričkom smislu, gradi na principu kontrasta, on oba opoziciona aspekta (identitet-srpsko / alteritet-švapsko) sagledava i sa dobrih i sa loših strana. Crnjanski, dakle, svestrane predstave o Švabama, kao heteroslike, baš kao i predstave o Srbima, gradi u vidu Pažoovog shvatanja imagema, tako da mu upravo kontrapunkt pomenutog opozitnog para, omogućava da, „oslikavajući“ švapski, 
istovremeno, plastično gradi i autoslike ${ }^{17}$ o vlastitoj zemlji i narodu (Dukić, Blažević, Plejić Poje \& Brković, 2009: 5).

\section{3. ŠVABE KAO UNUTRA $\check{S} N A$ DRUGOST U KRALJEVINI SHS}

Crnjanski zapaža da se kod Švaba, i nakon Rata, još uvek jasno uočava nekadašnji životni stil koji je bio opšte mesto svakodnevice austrougarske građanske kulture:

U Vršcu nemački deo varoši, na čiju su udobnost i ulepšanje dosad trošili sve prihode, uređen je asfaltom, električnim osvetljenjem, velikim palatama i ogromnom crkvom u stilu regensburške gotike, tako da dominira svu varoš. Uz taj švapski deo varoši je vrlo lep park, pun šetača i igrača tenisa, sa vrlo lepim sanitorijumom za slabe [...] Naša vojna muzika, svesna 'kulturnosti' vršačkih Švaba, svira im švapsku muziku nedeljom po podne“" (Crnjanski, 1989: 93).

Među Švabama ima mnogo "bogatih i školovanih ljudi“ (Crnjanski, 1995a: 62). Iako je u Vršcu ,zanat uglavnom u rukama Srba“ u tom poslu ima i „mnogo Nemaca" (Crnjanski, 1989: 102). Crnjanski ističe da se na svakom mestu gde su Švabe ,vidi njihova čudna organizovanost“, čak i u „restoranima: svi ćute, jedan govori“" (Crnjanski, 1989: 59). Iz diskursa se jasno sagledava bipolarni semiotički model, tako da, kada Crnjaski kaže naš, misli na Srbe, a kada veli njihov, misli na Švabe. Neophodno je istaći da su u putopisnom diskursu Crnjanskog, što je očigledno već iz sporadičnih primera, celom strukturom razasuti slični semiotički indikatori ,ambivalentnog binarnog polariteta“ (Pageaux) ili, kako bi to Lotman rekao, semiosferne distinkcije naš /njihov. Moura s tim u vezi ističe da je „svaka slika o Drugom iskrivljena“, a tu tezu temelji na tvrdnji da su „Druga zemlja i narod uvijek promatrani radi isticanja vlasitog identiteta“ (Blažina, 2010: 478). S tim u vezi, iako bi se moglo učiniti neobičnim, u Crnjanskovim slikama našeg njihovog čini se da je više negativnosti na našem, odnosno srpskom, nego na njihovom, odnosno švapskom imagemu. Takav se stav nameće iz opservacije da Crnjanski u referentnim putopisanjima zaista ne štedi ni državu, ni vlast koju, većinski, konstituše srpski i drugi slovenski živalj u Kraljevini.

Naznačeni fenomeni proističu iz neosporne činjenice da $\mathrm{u}$ istom kulturnom kontekstu, različite socijalne grupe (u semiotičlom smislu, kulturne substrukture), imaju različite vrednosne sisteme. Konkretne putopisne slike Crnjanskog svedoče o tome da je vrednosni sistem, na primer, kod banatskih Švaba, a po uzoru na vrednosni sistem autohtone kulture bavarskih Švaba, od kojih su banatske Švabe i potekle - sveočigledno dominantno utemeljen u raciju, radu, vrednoći, disciplini,

17 O autoslikama i heteroslikama (u smislu autopredsrava i heteropredstava), odnosno o autopredodžbama i heteropredodžbama, detalnjo govori Davor Dukić u tekstu „Predgovor: O imagologiji“ koji je objavljen u tematskom zborniku: Dukić, D., Blažević Z., Plejić Poje L., \& Brković I. (prir.) (2009). Kako vidimo strane zemlje - uvod u imagologiju. Zagreb: Srednja Europa. 
štednji, dobroj organizaciji i nacionalnom jedinstvu. Crnjanski zapaža da su složne u mišljenju, tako da ono što jedam od Švaba veli „to i ostali kažu“ (Crnjanski, 1989: 59). Nakon Prvog svetskog rata, u kontekstu brojčano nadmoćne, dominantne srpske matice, banatske Švabe, kao manjina u Kraljevini SHS, žele da očuvaju svoju tradicionalnu matricu svakodnevice, tako da je njihov stil života ostao s pogledom na prošlost: vekovima negovan u okrilju Habzburškog carstva, ostavio je duboke i trajne tragove i u njihovoj svakodnevici u novoj državi.

Crnjanski se, na primer, živo seća da je, u vreme njegovog detinjstva, Temišvar s kraja 19. veka, bio ,varoš raskošna, moderna, sa širokom avenijama, velikim parkovima, velikim klubovima na vodama, ali i industrijskim predgrađima. Imao je ogromna egzercirišta i groblja. Imao je nadimak Mali Beč.“ (Crnjanski, 1989: 31) jer mu je Beč i bio uzor: „U srcu varoši bio je barokni centar grada, sa velikom, katoličkom, katedralom, čuvemom sa koncerata Baha, sa manastirima katoličkih fratara, među kojima je jedan, pijarista, bio moja škola.“ (Crnjanski, 1989: 31). Nasred Temišvara, svake nedelje, kad je vreme lepo, svirala je vojna muzika, na trgu, opkoljena terasama restorana i slastičara. Svet se tu šetao, kao što se u Italiji šeta“ (Crnjanski, 1989: 31). Raskošan i „ogroman, sa svojim vanrednim avenijama [...] usred grada, oko petokatnih kuća, luksuz je bio neizmeran [...]" (Crnjanski, 1989: 48). U korak s tadašnjim najrazvijenijim ,gradovima evropskim [...] čim je prvi avijatičar načinio vratolomije nad francuskom nebom“ već je „bio na temišvarskoj poljani, da to pokaže“ (Crnjanski, 1989: 48). Temišvar je, dakle, po uzoru na Beč, usvojio građanski stil života svojstven Zapadnoj Evropi s kraja 19. i početkom 20 . veka.

U vreme odmora, razlike među pripadnicima različitih nacionalnosti su manje uočljive i bolje su tolerisane. Nedaleko od pomenute ,temišvarske poljane [...] iza ogromnog i svetskog kupatila, i petokatnih hotela [...] moglo je da se nađe birtija sa opranim patosom, gde su nedeljom sluškinje igrale uz trumbetu" (Crnjanski, 1989: 48). I tada su Švabe imale važnu ulogu, a njihova dobra organizovanost padala je u oči:

Švapski trubač vršio je svoju dužnost vrlo jeftino i savesno i čudno. Zasvirao bi u jednom birtu i duvao, dok se parovi ne upute, pa pretrčao preko ćoška u drugi, i tamo započeo isto, sve dok se nije sve vrtelo kao podmazano, da se brzo vrati u pređašnji birt, gde su poneki počeli da ispadaju iz takta, pa ih opet uduvao u krug. (Crnjanski, 1989: 48-49).

I nakon Rata, u novom sistemu i pod novom vlašću, banatske Švabe se trude da očuvaju svoj tradicionalni stil svakodnevice: „Nemački deo varoši (Vršca) na čiju su udobnost i ulepšanje dosad trošili sve prihode, uređen je asfaltom, električnim osvetljenjem, velikim palatama i ogromnom crkvom u stilu regensburške gotike, tako da dominira svu varoš“ (Crnjanski, 1989: 93). Pripadnica različitih nacionalnih entiteta zajedno provode slobodno vreme na prigodnim javnim prostorima: „Iza tog švapskog dela varoši je vrlo lep park, pun šetača i igrača tenisa, sa vrlo lepim sanitorijumom za slabe“ (Crnjanski, 1989: 93), a iz 
Crnjanskovih opaski jasno se vidi da je, u vreme dokolice i zabave, narod nacionalno pomešan: „Naša [srpska] vojna muzika, svesna 'kulturnosti' vršačkih Švaba, svira im švapsku muziku nedeljom po podne" (Crnjanski, 1989: 93).

Čak se i po selima kulturni život odvija organizovano u zajedništvu „,različitosti““. Tako, kada je Crnjanski stigao u Lazarevo „bio je dečji dan [...] Uveče u malom pozorištu, priređene su predstave i deca su bila obučena kao anđelčići. Sve je bilo lepo, i Mađari i Nemci i Jevreji i Srbis [...] sva deca po grupama izvode svoje prikaze" (Crnjanski, 1989: 21).

Za vreme Crnjanskovog obilaska Banata ,stare Švabe, koje su prilazile kolima da govore sa novinarem uglavnom nisu hteli da se tuže na novu vlast i svoj položaj“ u poratnim okolnostima (Crnjanski, 1995b: 61). Međutum, nisu mogli da oćute pojave koje su za njih bile toliko tuđe da ih nisu mogli niti razumeti, niti se sa njima pomiriti. Naime, žalili su se ,na žandarme, koji hoće da siluju devojke, što je kod njih nečuveno“" (Crnjanski, 1995b: 61). Crnjanski zapaža da Švabe retko prave ekcese, iako se, oseća da „,novu vlast ne prihvataju“: „Svega jedan slučaj u Sečnju [...] pijani svatovi [...] zderali su državni grb sa opštine" (Crnjanski, 1995b: 61-62). Posledice toga događaja za Švabe su, međutim, ponovo, bile neshvatljive, jer nisu sledile iz regularnih kaznenih normi, već iz tradicionalnog, odomaćenog, narodnog običaja:

Naši su im [zbog kidanja državnog grba] mesto zatvora opalili po nekoliko, možda i dvadeset pet. To im nikako nije išlo u glavu i celim putem jadali su mi se zbog toga. Razlozi njini bili su vrlo zanimljivi: 'Ta to su Śvabe, bogati ljudi, školovani ljudi'“ (Crnjanski, 1995b: 62).

Za Švabe je kršenje državnih normi - neprihvatljivo, pogotovo kada to čine neposredni predstavnici vlasti - žandari.

Međutim, švapska Drugost se naročito jasno očituje na fonu nestabilnih društveno-političkoh okolnosti u prvim poratnim godinama u Kraljevini Srba, Hrvata i Slovenaca, o kojima Crnjanski govori u referentnoj putopisnoj prozi, a koje su bremenite političkim i stranačkim previranjima, ekonomskim nedaćama, te posledicama neuspešne agrarne reforme. Pođimo od žile kucavice, saobraćaja - koji je preduslov privredno-ekonomskog razvoja. Crnjanski svedoči o tome da su međumesni putevi u očajnom stanju. Rad na poljima, i saobraćajna komunikacija je zbog toga veoma otežana. Prilikom svoje putopisne ekspedicije, vozeći se „autom po Banatu [...] između /zaprežnih/ kola, volova, ovaca, orača, kopača što mile i jedva se miču [...]“ Crnjanski zapaža da ,auto i ne ide drumom [...] jer su oni, posle rata [...] zapušteni i razriveni, niko o njima ne vodi brige" (Crnjanski, 1989: 113). Država, zbog toga, pokušava da uvede javne radove, nametom, kao svojevrstan kuluk, ali se, većina stanovništva, na te radove ne odaziva. Crnjanski zapaža da „dužom kraj njih /drumova/ leže samo tovari kamenja, što su bačeni na puteve pred izbore, u doba obećanja i varanja“ (Crnjanski, 1989: 113). Dok se voze autom, ,putem susreću dvoje-troje kola natovarena drumskim kamenjem. To kuluče za drum. U stvari, kuluk, kojim se u Banatu čini nečuveno nasilje i 
srednjevekovni užas, niko i ne drži. Radikali ne kuluče, među demokratama samo oni koji su plašljiviji [...]“ (Crnjanski, 1989: 113).

Crnjanski, očigledno, ne odobrava ovaj potestarni program, tvrdeći da je reč o ,nečuvenom nasilju i srednjevekovnom užasu“ i kao da se stavlja na stranu naroda koji se o normu oglušava. Međutim, poštovanje potestarnih zahteva i zvaničnih uredbenih normi - za Švabe je nešto što se podrazumeva, čak i kada se sa tim ne slažu. Oni, ipak, kuluče, što Crnjanski decidirano veli, i to ističe kao posebnost u njihovom ponašanju: ,,[...] kuluči jedino po neki Švaba [...]“ (Crnjanski, 1989: 113). Međutim, taj njihov odziv podsmešljivo komentariše, tvrdeći da kuluče zbog toga što su se ,prepali od kazne kojom se preti“ (Crnjanski, 1989: 113). Ista je situacija i u naseljenim mestima u Banatu: „drumovi su sve gori i gori, ogromne rupe, jendeci presecaju put, a pred samim opštinskim zgradama, kola se zaglibe u blato. Vratila se vremena od pre sto godina“"(Crnjanski, 1989: 113). Međutim u Žombolju, na primer, gde su Nemci većinski živalj, prvi utisci za Crnjanskog su fascinantni i zadivljujući: ,putevi su popravljeni“, a putnike namernike „Žombolj dočekuje vrlo lepom [železničkom] stanicom, kao varoš“ (Crnjanski, 1989: 57).

Kada je reč o poljoprivredi, obradiva zemlja je zaparložena, tako da se po celom Banatu, vidi ,pokor agrarne reforme“18 (Crnjanski, 1989: 22). U nju su „umešali prste i radikali i demokrate, da ne misli neko da su demokrate bolje bile, naprotiv“ (Crnjanski, 1989: 82). „Upropašćena divna i plodna zemlja [...] More zaparložene zemlje, korova, baruština“ (Crnjanski 1989: 23). Crnjanski veli da „nigde u Banatu ni jednog čoveka ne nađoh, koji je verovao u dobivenu zemlju [...] Afera, partija, optužbe, spletke [...] A svuda uokolo neobrađena polja, poljoprivredne mašine, što već godinama stoje na kiši upropašćene [...] Jad i ludnica u ekonomiji“ (Crnjanski, 1989: 83).

Lošom državnom ekonomskom politikom nisu pogođeni samo seljaci već i krupni privrednici, među kojima ima mnogo Nemaca. Primera radi, Crnjanski je u Kikindi, posetio mlin ,jjedan od najvećih u državi“" pa povodom toga veli: "Dočekali su me direktori [....] Leo Brandajs i [...] Feliks Fišer, koji drže ogromnu mlinarsku industriju“ i gotovo je sva „trgovina žitom" u njihovim rukama“ (Crnjanski, 1989: 73). Zapaža da su ,akcije ostale u rukama Pešte i Beča“ (Crnjanski, 1989: 73). Gospoda Brandajs i Fišer ističući Crnjanskom da je posvuda „stran kapital [...] sve je stran kapital“ (Crnjanski, 1989: 73). Poentiraju: „Napišite vi da je glavno da ga ima i to što više [...] Novac ne zna za nacionalizam" (Crnjanski, 1989: 73-74). Vatreno su Crnjanskom izneli gorući problem, aferu sa žitim, u kojoj je glavne konce vukla korumpirana politička elita u samoj Vladi:

Pišite vi o tome da je ova država sama sebi najveći protivnik. Evo vam originalno pismo [...] Talijani nam konkurencijom oteše svu Jadransku obalu, prodajući, bud zašto, brašno [...] Talijani koji ni za sebe nemaju brašna, mogu

„Da bi smirila revolucionarna raspoloženja“ podstaknuta Oktobarskom revoljucijom 1917. u Rusiji, „vlasti Kraljevine SHS su bile prinuđene da 25.02.1919 donesu Odredbe za agrarnu reformu [...] a sve političke partije u Kraljevini SHS prihvatile su sprovođenje agrarne reforme kao nužnu meru“ (Gaćeša, 2002: 73). 
nama da konkurišu, zato što nemaju nikakvog tereta, carina. Vlada im je to sasvim zbrisala. To vi napišite, toga nema nigde na svetu. Izgubili smo Dalmaciju, Gruž i Hercegovinu, Albaniju, a sve je to pre rata kupovalo od nas. A znate li zašto je to tako? Zato što je mama ministra trgovine Talijanka - verujte znamo mi to (Crnjanski, 1989: 73-74).

Švabe smatraju da je država glavni krivac za haotično stanje i nezavidnu ekonomsku situaciju u zemlji, pre svega zbog tolerisanja korupcije koja je preplavila državnu vlast i administraciju. O tome javno govore. Sam Crnjanski veli da su na sve strane: „užasne afere carinarnica, činovnika [...]“ (Crnjanski, 1989: 61).

Visokokoruptivni kontekst nove države „sve većem broj pojedinaca koji su iskorenjen iz svoje rodne sredine [...] nije uspeo da postane prihvaćeni novi dom" jer je društvena nestabilnost pojačavala osećanje nesigurnosti (up. Berger \& Kellner, 1974: 165; podvukao autor rada). Upravo sinergija nepovoljnih okolnosti, kao kulturološki lakmus, živo i upečatljivo identifikuje i ističe problematiku banatskih Švaba u novoformiranoj državi. Po putopisnom svedočenju Crnjanskog, Drugost banatskih Švaba oblikuje se, i posebno ističe, upravo zbog svoje suprotnosti opštem haosu u Kraljevini.

\section{4. ŠVAPSKA DRUGOST: METISOM PROTIV DRUŠTVENOG HAOSA}

U međusobnom prožimanju izrazitih specifičnosti u domenu švapske svakodnevice i, s tim u vezi, njihove političke organizovanosti i delovanja, koje $\mathrm{su}$, u datom preovlađujućem kulturnom kontekstu Kraljevine SHS, recipirane kao upečatljive različitosti - konstituisana je i negativna recepcija Švaba kao unutrašnje Drugosti.

Crnjanski zapaža da su Banatske Švabe kontrapunkt političkom haosu i ekonomskoj učmalosti u koju je zapalo društvo Kraljevine Srba, Hrvata i Slovenaca. Oni su u tom kontekstu aktant ,ideološkog rezonatora“ upravo u onom smislu o kome govori Leerssen. Ne prihvataju da su deo pomenutog miljea i odupiru mu se efikasnijim stilom života. Enklaviraju se u unutrašnju Drugost koja kritički posmatra centar moći i „legitimno postojeći poredak“ (Bojcov 2010: 16), a život organizuje $\mathrm{u}$ duhu habituelizacije uz primenu metis ${ }^{19}$ tehnika, kao vida „svakodnevnog otpora“ kontekstualnom stanju (Spasić, 2012: 80). Mišel de Serto [Michel de Certeau] ističe da metis, kao ,umjetnost slabog“, kao, dakle, svojevrsna

19 Lat. Metis: označava inteligenciju, kvalitet koji povezuje mudrost i lukavost, osobine visoko cenjene u antičkoj kulturi (Srejović, Cermanović-Kuzmanović, 1979: 263). Isto i starogrčki Metida (Mñ ıı): po grčkoj mitologiji, prva Zevsova žena. Zbog proročanstva da će Zevsa svrgnuti njegovo i Metidino dete, Zevs je Metidu, kada je začela Atenu, laskanjem pretvorio u pčelu, a zatim ju je progutao. Dospela je u Zevsovu glavu iz koje se rodila Atena. Metida je ostala u Zevsovoj glavi da bi ga savetovala o dobru i zlu. U književnosti, Odisej je simbol i ovaploćenje veštine metis (prema Srejović \& Cermanović-Kuzmanović, 1979: 263). Mišel de Serto [Michel de Certeau] koristi ovaj izraz da bi objasnio specifične oblike ponašanja u praksi svakodnevnog života. 
„umjetnost preživljavanja“, podrazumeva inteligentno služenje taktikom kojom „slabo nadvladava snažno i moćno“, na primer vlast; kojom se „grabe prilike“, manipuliše datim odnosima, okolnostima i situacijama, kako bi se oni preokrenuli u korist manipulatora (Certeau de, 2002: 93-95). Suština habituelizacije ogleda se u sistematičnoj i organizovanoj „rutinizaciji egzistencije, odnosno pretvaranju svakodnevice u niz uobičajenih procedura [...]“ koja omogućava „funkcionisanje pojedinca unutar složenog, polistrukturnog društva i kulture [...] naročito u teškim uslovima kada pojedinac oseća da je prepušten samom sebi“" (Stojković, 1996: 255). Upravo u skladu s rečenim, istaknimo: misleći na mirovni status nakon Prvog svetskog rata, sam Crnjanski veli da je Švabama „oslobođenje [...] palo kao cigla na glavu, sloboda im je donela neki tihi stid, pa ćute, trpe i rade" (Crnjanski, 1989: 19).

Jasno je da u neorganizovanom i korumpiranom društvenom miljeu - metis jeste za banatske Švabe bio izraz socijalne inteligencije koja im je omogućavala da ekonomski i nacionalno-manjinski opstaju u Banatu. Jer, kako da poštuju vlast, koja samu sebe ne poštuje? To je osnovno, indirektno pitanje koje se nameće banatskom Švabama iz ukupne društvene hipokrizije u Kraljevini i koje ih, ujedno, usmerava ka metisu, kao mogućnom rešenju. Na primer, za razliku od drugih žitelja Banata, koji se zbog loše sprovedene agrarne reforme „tuže da nemaju žita za zimu“, Švabe se samoorganizuju, planiraju i pomažu, uspevajući tako da situaciju preokrenu u svoju korist. One Švabe koje su se u vreme kolonizacije, iselile za Ameriku ,sad šalju novce kući i kupuju svaki komadić zemlje koji je za prodaju. Ne samo da nisu propali, nego [...] sakupiše za nekoliko dana, nekoliko hiljada dinara" i odmah su novac uložili u kupovinu oranica (Crnjanski, 1989: 86). Stoga, bilo da je reč o ataru kod Lazareva, Sarče, ili nekog drugog banatskog sela, vidi se uvek ista slika „ogromna ravnica [...] Nemci sa dobrim konjima i starim porodičnim malim posedima“; oni su prvi ,orači na obzorju (Crnjanski, 1989: 21-22). I dok se po krčmama raspredaju ,izbori, radikali, demokrate, advokati, agrarni referenti, sijaset inspektora“, dok se ,pričaju anegdote kako su postala i nestala ta mala imanja [...] Švabe uokolo jeftino zakupljuju zemlju“ i odmah počinju da je obrađuju (Crnjanski, 1989: 23). Kada nemaju svoju, oni obrađuju tuđu, uzetu pod „,arendu“, tako da se „,uokolo, vide gde oru Švabe, napoličari Ličana“ kolonista, za koje Crnjanski, u istom kontekstu, uz put veli „brdski je to svet, čudan i lenj“ (Crnjanski, 1995b: 70-71). Crnjanski zaključuje da Švabe:

Agrarna reforma [...] ne tuče. Svaka porodica, podeljeno na sve članove, ima dosta zemlje. Na mnogo mesta zakupili su zemlju razdeljenu Srbima agrarnom reformom, a naročito zemlju kolonista, naseljenika ${ }^{20}$. Od Sečanja

20 „Tokom sprovođenja agrarne reforme pripadnici neslovenskih nacionalnih manjina bili su isključeni kao njeni korisnici. Time je bilo istaknuto nacionalno (srpsko) obeležje reforme“ (Gaćeša, 2002: 74). Zemlja je deljena „,bezemljašima, dobrovoljcima i brđanima kolonistima“ (Gaćeša, 2002: 75). Tu razdeljenu zemlju činili su nacionalizacijom oduzeti ,,posedi u vlasništvu zemljišne aristokratije uglavnom mađarskog i nemačkog nacionalnog porekla“ (Gaćeša, 2002: 74). „U kolonizaciji Vojvodine preplitali su se socijalni i nacionalno-politički motivi“ (Gaćeša, 2002: 75). 
čak pod Vršac sretao sam Švabe, što oru podeljenu zemlju“ (Crnjanski, 1995b: 62).

Putopisac ih zbog svega toga poštuje i to beleži u direktnom svedočenju: „Treba priznati, nisu je [zemlju] dobili prevarom, već superiornošću svojih domazluka, stoke i rada (Crnjanski, 1995b: 62).

U širem kontekstu, Švabe se, upravo zbog svog drugačijeg ponašanja, zbog utiska koji na druge ostavljaju da žive u izobilju, da ni u čemu nisu prikraćeni, dok većina grca u haosu -doživljavaju kao Drugost. To se naročito ističe tamo gde su oni najbrojnije stanovništvo, na primer u Žombolju ,sa četrnaest hiljada Švaba, od kojih su vrlo mnogi milionari [...]“ a Crnjanski zapaža da tu,,[...] ima kuća koje i po modernosti i po nameštaju mogu stojati nasred Terazija. Kafane i restorani su vrlo dobri, hoteli vrlo čisti, Švabe vas dočekuju svuda sa mlekom. Žito im je čuveno čak u Americi i sirotinje tu nema“" (Crnjanski, 1989: 57).

$\mathrm{Na}$ osnovu Crnjanskove putopisne faktografije, a pre svega na osnovu svedočenja samih Švaba o korumpiranosti državnog sistema i opštem haosu u privredi i ekonomiji - čini se da Crnjanski, profesionalno, teži objektivnosti u predstavljanju i srpske i nemačke strane.

\section{IRONIJOM NA ŠVAPSKU DRUGOST}

Crnjanski, takođe, ukazuje i na izvesne negativne aspekte švapskog imagema koji su, upravo sinergijom, kumulativno, doprineli takvom nepovoljnom potestarnom pozicioniranju Švaba, da ih se Država „odrekla“, odnosno da ih je „tako lako dala Rumunima“" (Crnjanski, 1989: 59). Reč je o njihovoj indiferentnosti, apatičnosti prema drugima, njihovom apriornom superiornom postavljanju $\mathrm{u}$ odnosu na druge, o čemu Crnjanski svedoči na više mesta u naznačenim pitopisima; o njihovom „,neopisanom samopouzdanju“; o njihovoj „strahovitoj uobraženosti i pouzdanju u sebe, a drskosti prema nama" što stvara imagem o švapskoj oholosti (spram Crnjanski, 1995b: 62).

U diskursnom predočavanju negativnih aspekata švapskog imagema Crnjanski se najčešće koristi ironijom ${ }^{21}$, pejorativom, pejorativnom metaforom, metonimijom i njenim raznim oblicima (pars pro toto). Sporadične naznake stereotipizacija, vezane za Švabe kao unutrašnje Drugosti, kod Crnjanskog je moguće uočiti jedino u njegovom, povremenom, ironijskom diskursnom distanciranju od njih. Gotovo po Zindamovom obrascu i njegovom zapažanju o ,ironijskoj primjeni nacionalnih stereotipova u književnom tekstu“" (Blažina, 2010: 476). Tako, primerice, Crnjanskog pogađa hladan, racionalni, apatičan odnos Švaba prema gotovo svemu što se ne tiče njihovog ličnog statusa. ,Sav posleratni haos, politički, psihički, njih

21 Zindam [Syndam] ističe ,važnost istraživanja percepcijskih učinaka imagotipskih predodžbi, te uočavanja ironijske primjene nacionalnih stereotipova u književnom tekstu“ (Blažina, 2010: 476). Zaključuje da ,imagologija ima zadatak analizirati stupanj važnosti nacionalnih predodžbi u umjetničkoj, povjesnoj i društvenoj sferi“ (Blažina, 2010: 476). 
malo zanima“ (Crnjanski, 1989: 57) . Sve su Švabe ,jednako započinjali sa `mi Švabe“" da bi potom „raspalili svoje grdnje, savete i uvrede [...] jer hoće da budu poštovani [...] Ustvari, oni su sastavili svoj život iz mleka, masti, konja, novaca, a sve drugo ih se malo tiče“ (Crnjanski, 1989: 57). Gde god mogu „drsko i grubo ismevaju nered u državi, korupciju činovnika, radikale i demokrate. Sebe hvale“ (Crnjanski, 1989: 59). Takvo stanje u državu, Crnjasnski, videli smo, ne opravdava, ali mu smeta što se Švabe tome izrugaju. Zamera im što:

glasno galame svud i zahtevaju svoje po železnicama i zvanjima. Neopisano je to švapsko samopouzdanje, kad izgovore 'ein deutscher Mann'. U stvari bogati i ugojeni, gledaju svoj trbuh i naše patnje i državu sasvim indiferentno. Ostaju tu na bogatoj ravnici gde su ih carevi naselili, jedu i piju i rade za sebe“ (Crnjanski, 1995b: 62).

Crnjanskog iritira to što su komunikaciju „oholo započinjali 'mi Švabe', pa rasipali svoje grdnje, savete i uvrede“ (Crnjanski, 1989: 57). Posebno ga pogađa švapska nezainteresovanost za „tuđu muku“, za sve ono u čemu ne prepoznaju svoj interes, pa reaguje vrlo emotivno: „Po kućama u bogatstvu, oni su sasvim odvratni. Jedu i piju i to je sve. Zato im treba mir i red"; na momente ironično: „Rat je na njih slabo uticao [...] još je malo više vanbračne dece, inače je sve po starom (Crnjanski, 1989: 58; kurzivom istakao autor ovog radate). Jetko primećuje: „Ima porodica čiji su đaci u Nemačkoj i Beču. Od tih mladića većina se vraća sa značkama habzburgovskim i bavarskih fašista [...] sa duševnim vezama u Austriji [...]. O tome malo govore, ali za vođe se vezuju istim sudbonosnim poverenjem, kao i nemačke mase" (Crnjanski, 1995b: 62). Iz navedenoga ponašanja Švaba, kao i zbog njihove spremnosti na ,slepu“ poslušnost svom izabranom vođi, vidi se izvesno Crnjaskovo nepoverenje i rezervisanost prema njihovim namerama, koje, tada, još nisu javno artikulisane, ali su indikativne jer potenciraju Drugost.

Putopisac zapaža da su se Švabe, gledajući samo svoje interese i osvajajući privilegije za sebe - otuđili od većinske zajednice i sami doprineli tome da u njoj postanu unutrašnja Drugost. Za njih je:

odnos prema državi SHS značio obezbediti krave, konje i mleko i, sa što manje sudara, švapska prava, što znače malu porezu, nemačke učitelje i, naročito, da sinovi ne služe (vojsku) u Makedoniji, gde ima malarije i kačaka, a poznato je da to za Švabe nije [...] U ime ljudskih prava, u ime kulture, u ime Evrope, oni mole, ištu, zahtevaju samo jedno: da Švabama bude dobro. To je njin program. Kada se sve to reši, ostalo sve neka đavo nosi, njih se malo tiče“ (Crnjanski, 1989: 58). „U zamenu za to oni će biti lojalni, mirni, jesti i piti i živeti među nama još dva stoleća, bez tragedija. U stvari taj mnogo i oholo hvaljeni švapski život znači gomilu egoističkih, debelih seljaka i pokorno razvratnih žena (Crnjanski, 1989: 59). 
Crnjanski kritički opservira švapsku moralnu orijentaciju utemeljenu u habituelizaciji i metisu, upravo onako kako ga tumači Mišel de Serto - a kojom teže da, ,grabeći prilike“, raznim manipulacijama i prevrtljivostima prema vlasti, preokreću i prilagođavju date odnose i okolnosti u svoju korist, kako bi „obezbedili samo to da njima bude dobro" (Crnjanski, 1989: 60).

Istina je da se Crnjanski od Švaba naslušao neverovatnih stvari o ,užasnim aferama carinarnica, činovnika" i drugih predstavnika vlasti (Crnjanski, 1989: 61). Međutim, ni švapski „odgovori“" na takve pojave, nisu bili ništa moralniji. Primera radi, „Fabrikant Trajs, sumnjiv vlastima politički, morao je da plati ogroman porez, a rečeno mu je da je to zato što je vođa Nemaca" (Crnjanski, 1989: 61). U toj situaciji, javlja se snaga metisa: „Trajs je nabavio ključ plaćanja poreza $i$ zakonske naredbe, koje se baš ne pokazuju inače. Kad sam ga pitao otkud, on se nasmejao i rekao mirno: 'Lepo iz ministarstva, od g. Nikolića, imam i ja prijatelja'، (Crnjanski, 1989: 61; podvukao autor rada). Morao je, dakle, da se metisom „snađe“ da bi ,isterao pravdu“.

U političkim igrama između radikala i demokrata, Švabe gledaju svoje interese i „grabe svoje prilike“ takođe se služeći metisom. „Divno je čuti ih [Švabe] kako pričaju i kako se smeju radikalima i demokratama, koji su dolazili da pregovaraju [o glasanju na izborima]“ (Crnjanski 1989: 59). I jedni i drugi su im „obećavali trista čuda. Svakom selu kraj Dunava most, svakom Švabi besplatnu zemlju i škole. Nazivali ih 'braćo Švabe'[...]“ (Crnjanski, 1995b: 61). Međutim, „romantike kod njih nema [...]" (Crnjanski 1995b: 61). To je trezven svet, „,ne veruju, nikome“, samo svojima (Crnjanski, 1989: 59). „Zato su svi u jednoj partiji, u nemačkoj partiji, zato su svi u jednom savezu, u 'Kulturbundu', zato su svi glasali za jednog kandidata, za svog Švabu“ (Crnjanski, 1989: 57). Što su političke igre između radikala i demokrata bile žešće, Švabe su se sve više međusobno udruživale i koristile metis tehnike. Tako je pri poslednjim izborima ,čak i g. Kolbus, Švaba, radikalski kandidat, glasao na drugog Švabu, a ne na sebe. 'Gospodine, mi smo Švabe, svi smo u Kulturbundu, svi smo za nemačku partiju. Smešno je da su poverovali da ćemo glasati na njih" radikale (Crnjanski, 1989: 61; podvukao aurot rada) koji su, tako, na švapsku prevaru, ,izgubili dva poslanika“ (Crnjanski, 1989: 60-61). Već sama kontrastna diferencijacija na naše i njihovo, sa živim „dijaloškim“ izmenama tih dveju pozicija, koje u svom diskursu retorički podcrtava Crnjanski - svedoči o dubini obostranog međusobnog političkog nepoverenja i neprihvatanja. $\mathrm{S}$ jedne strane, neprihvatanje potestarnih i drugih kulturoloških rešenja koja su kontekstom ponuđena Švabama. S druge strane, potestarni kontekst Kraljevine, ne prihvata Śvapsku Drugost ovaploćenu u apatičnoj habituelizaciji i metisu.

\section{POTESTARNI BUMERANG}

U neorganizovanom i korumpiranom društvenom miljeu - metis jeste za banatske Svabe bio izraz socijalne inteligencije koja im je omogućavala da ekonomski i nacionalno-manjinski opstaju u Banatu, ali istovremeno, metis je bio 
i veoma bitan činilac oblikovanja švapske Drugosti u unitrašnje tuđe telo kojeg se šira zajednica „tako lako“ odrekla (Crnjanski, 1989: 59).

Naime, ubrzo je usledio potestarni bumerang: između Kraljevine SHS i Rumunije je „potpisana konvencija po kojoj varošica Žombolj i još neka sela u severnom Banatu, prelaze u Rumuniju, u zamenu za neka mesta naseljena našim [srpskim] življem““22 (Crnjanski, 1989, 55). „Švabe su bile kivne“ (Crnjanski, 1989: 57). Radikali su „trgovali sa granicom [...] ucenjujući i tražeći mito“ (Crnjanski, 1995: 85). Crnjanki je te glasine o korumpiranosti i manipulacijama radikalske vlasti proveravao u razgovoru sa Jocom Budišinim, istaknutim radikalom, koji „po Kikindi vedri i oblači“ (Crnjanski, 1995: 85). Upravo je on Crnjanskom potvrdio istinitost glasina i „obasipao ga spletkama“: „Sve je istina o Žombolju što se priča [...] Pozivali su gazde [Švabe] da plate, pa će pripasti nama, ako ne plate, hatar ostaje u Rumuniji“ (Crnjanski, 1995: 85). Pri tome, sve su te manipulacije, primećuje Crnjanski, u nastojanju da bude objektivan i neutralan u beleženju faktografije, izvođene „sa jednom seljačkom brutalnošću“ (Crnjanski, 1995: 85).

Švabe su uverene u to da je reč o ,osveti zbog toga što su na izborima prevarili kikindske radikale" (Crnjanski, 1989: 61). Kada su postali svesni da ih se Kraljevina SHS odrekla, da bi za uzvrat, po rečima Švaba, dobila „ona bedna srpska sela u kojima nema ni pola toliko Srbalja, koliko zvanični izveštaji kažu“ onda ih je ,zahvatila melanholija“" (Crnjanski, 1989: 60; podvukao autor rada):

Ovde su imali škole, svoje saveze, partiju i Žombolj je živeo, kao na sred Nemačke. Sad ih izbacujemo iz države, a niko ih ne pita hoće li da idu. Ni jedna država na svetu, još nikad to nije učinila. Žombolj vredi više od Beograda, toliki konji, toliko žita, tolike uredne i čiste Švabe, a mi ih dajemo, tako lako dajemo (Crnjanski, 1989: 59)23.

Putopisac rezimira da Švabe nemaju izražene asimilacijske intencije, ali i da odbijaju elemente tuđeg, na primer, srpske kulture, što jeste svojstveno kontrakulturaciji: "Nisu tvrdoglavi, neće da pošvabe, ali neće ni da se posrbljuju“ (Crnjanski, 1995b: 61).

22 "Razgraničenje između Rumunije i Kraljevine Srba, Hrvata i Slovenaca sprovedeno je sporazumom potpisanim u jesen 1923. Po tom sporazumu je Kraljevina SHS ustupila Rumuniji: Žombolj, Žam, Čordu, Stari Beb i Pusta Kerestur, zatim nenaseljeno ostrvo na Dunavu Moldavu. Za uzvrat Rumunija ustupa Kraljevini SHS mesta: Modoš (Jaša Tomić), Pardanj (Međa), Šurjan, Veliki Gaj i Krivu Baru. Pored toga i ostrva na Dunavu, Ogradinu i Pleviševicu i 1.203 hektara zemlje duž suvozemne granice u Banatu i to: u Mokrinu 569, Velikom Gaju 102, Šurjanu 114, i u Klardiji (Radojevu) 418 hektara” ( Mečkić, web: pasus 3.). Primopredaja teritorije Žombolj izvršena je 1924. godine (spram . Đukić, web: pasus 2.).

23 „U međuratnom periodu, položaj Dunavskih Švaba u Jugoslaviji bio je nešto bolji nego u predratnoj Ugarskoj, jer su imali više mogućnosti za negovanje svog jezika i kulture“ (Dunavske Švabe. Istorija, web: pasus 4.). 


\section{POENTE}

$\mathrm{Na}$ osnovu referentnih putopisnih izveštaja Crnjanskog, u skladu sa mišljenjem Dizerinka da "imagolozi moraju dokazati način delovanja predodžbi, a ne ih samo prikupljati" u radu su, sa pozicija potestarne imagologije, predočeni i protumačeni bitni aspekti Švaba u pozociji unutrašnje Drugosti u Kraljevini Srba, Hrvata i Slovenaca (Blažina, 2010: 475).

Po Crnjanskovom imagemu o banatskim Švabama, one su i nakon Prvog svetskog rata, nastavile da žive svojim tradicionalnim stilom, oblikovanim sistemom vrednosti habzburške kulture jer im je to omogućeno konkretnim potestarnim rešenjima Kraljevine SHS. Međutim, brinući, mahom, samo o svojim interesima, apatični i podozrivi prema drugim subjektima i okolnostima u kontekstu; insistirajući na privilegijama, ,živeći samo za sebe“ i „štiteći samo svoje interese“, iako su, po njihovim rečima, prema njima ,vlasti bile meke, oficiri vanredni i niko ih nije dirao" - oni su se, spram srpskog i drugog življa, upadljivo oštro opozicionirali u unutrašnju Drugost (Crnjanski, 1989: 59; podvukao autor rada). Takav njihov izbor ponašanja i delanja u privatnom i javnom životu, ukazuje na izvestan nedostatak njihove volje da se konstruktivnije uključile u rešavanje poratne opšte društvene i političke krize u Kraljevini SHS, te više doprinosu unapređenju života u zajedništvu različitosti u novoj državi koja - Crnjaski to sve vreme indikacijama pokazuje - „nije uspela da postane prihvaćeni novi dom“ banatskim Švabama (up. Berger \& Kellner, 1974: 165; podvukao autor rada). Pri tome, okolnosti da su pripadnici nemačkog nacionalnog entiteta, koji je, i zvanično, smatran krivcem za Prvi svetski rat, ogromne ljudske žrtve i materijalne gubitke, dodatno su uticale na to da se Švabe habituelizacijom i metis tehnikama pojačano enklaviraju u svom tradicionalnom kulturnom obrascu, sami doprinoseći stvaranju sveopšte odbojne slike o sebi, odnosno nepovoljne opšterduštvene klime prema njima. Na takav švapski imagem, stvoren dvadesetih godina prošloga veka (slojevit, ali, uglavnom, negativno recipiran u tadašnjem svakodnevnom, javnom, političkom i ekonomskom životu Kraljevine) odnosno, na takvu švapsku Drugost u naznačenom kontekstu, potestarni mehanizmi Kraljevine SHS, a u korist pripadnika srpskog nacionalnog entiteta, dali su svoj očigledan, negativan odgovor, delujući tako da država banatske Švabe ,odbaci“ kao ,strano telo“ i prepusti ih novoj državi, Rumuniji, o čemu, videli smo, upečatljivo svedoči Crnjanski u „Žombolju na točkovima“ (Crnjanski, 1989: 54-62; podvukao autor rada). 


\section{LITERATURA}

Građa - izvori:

Crnjanski, M. (1989). O Banatu i o Banaćanima. Novi Sad: Kniževna zajednica Novog Sada.

Crnjanski, M. (1995a). Putopisi I. Beograd: Zadužbina Miloša Crnjanskog.

Crnjanski, M. (1995b). Putopisi II. Beograd: Zadužbina Miloša Crnjanskog.

Ostala literatura

Berger, P. L., Kellner, H. (1974). The Homeless Mind, Penguin Books, London.

Blažina, D. (2010). „Uvod u imagologiju: Kako vidimo strane zemlje, ur. Davor Dukić Zagreb: Srednja Evropa, 2009“. U Radovi, vol. 42, 2010, Zagreb: Zavod za Hrvatsku povijest, Filozofski fakultet Sveučilišta u Zagrebu, 474-479.

Бойцов, М. А. (2010). „Что такое потестарная имагология?“. В: Властиь и образ: Очерки йойесйарной имаїолоїии. Отв. редакторы: Бойцов, М. А., Успенский Ф. Б. СанктПетербург: Алетейя. 5-47.

Certeau, M. de. (2002). Invencija svakodnevice. Zagreb : Naklada MD (Biblioteka Polilog; knj. 8).

Dukić D., Blažević Z., Plejić Poje L., \& Brković I. (prir.) (2009). Kako vidimo strane zemlje - uvod u imagologiju. Zagreb: Srednja Europa.

Đerić, G. (2005a). „O nemim i glasnim stereotipima: konstruisanje etničkog karaktera u usmenoj književnosti“. Filozofija i društvo, 2005, br. 26, str. 105-120.

Đerić, G. (2005b). Pr(a)vo lice množine. Kolektivno samopoimanje i predstavljanje. Beograd: Institut za filozofiju i društvenu teoriju, IP Filip Višnjić.

Đukić, Đ. (prir.) (1990). „Iz istorije štampe: Ratne reportaže iz Španije Miloša Crnjanskog“, Novinarstvo 3-4, 89-109. [trinaest reportaža M. Crnjanskog]

Đukić, Đ. (2014). „Jaša Tomić između sela i grada“. Politika Online. Objavljeno 08.11.2014. Preuzeto 18. 07.2015, sa: http://www.politika.rs/rubrike/Srbija/Jasa-Tomic-izmedju-selai-grada.lt.html

Đurić, D. (1997). Novinarska enciklopedija, Beograd: BMG.

Elijas, N. (2001). Proces civilizacije, Sremski Karlovci: IK Z. Stojanovića

Gaćeša, N. (2002). „O agrarnim reformama u novoj istoriji Vojvodine“, Nastava istorije, br.15, Godina VIII (2002), 71-89.

Končar, Z. Tabački, Lj. (1970). Uvek u borbi - monografija Kumana, Novi Sad: Savez udruženja boraca NOR SAP Vojvodine

Lazarević Radak, S. (2011). „Unutrašnja Drugost kao izvor straha: elementi horora u putopisnom izveštaju sa Balkana“. Etnoantropološki problemi, n.s. god. 6. sv. 4 (2011), 949- 965.

Lazarević Radak, S. (2012). "Analiza i interpretacija drugosti na granicama disciplina”. Jurnal Interkulturalnost. Preuzeto 12. 01. 2014. sa: http://www.academia.edu/2209366/Analiza_i interpretacija_drugosti_na_granicama_disciplina

Leerssen J. (2009). "Retorika nacionalnog karaktera: programski pregled”.U: Dukić D., Zinka Blažević Z., Plejić Poje L., \& Brković I. (prir.). Kako vidimo strane zemlje - uvod u imagologiju. Zagreb: Srednja Europa; 99-124.

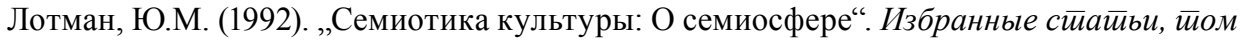

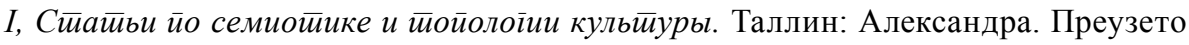
06.02.2010, ca: http://www.gumer.info/bibliotek_Buks/Culture/Lotm/index.php. 
Mečkić, L. (2015). „Period između dva svetska rata: Novi Bečej i Vranjevo kroz istoriju”.Novi Bečej Online. Preuzeto 18. 07. 2015, sa: http://www.novibechej.com/index.php/novi-beceji-vranjevo-kroz-istoriju/267-period-izmedu-dva-svetska-rata

Noris, D. (1993). „Finistere“. Književne novine 872-873, 15.10-1.11,1993. „Podunavske Švabe“ (2012). Udruženje Nemaca „Gerhard“. Preuzeto 18. 07. 2015, sa: http://www.gerhardsombor. org/sr/str-10-Podunavske-svabe.html

Smith, D. E. (1987). The Everyday World as Problematic: A Feminist Sociology. Boston: Northeastern University Press

Spasić, I. (2012). „Svakodnevno i političko: Kontrapunkt, otpor ili temelj?“ Političke perspektive 1, 2012, Beograd, 73-91.

Srdić, M. (ured.) (1979). Leksikon novinarstva. Beograd: Savremena administracija, Savremena knjiga, Savremena praksa.

Srejović D., Cermanović-Kuzmanović A. (1979). Rečnik grčke i rimske mitologije. Beograd: Prosveta.

Stojković, B. (1996). „Proces enkulturacije i odnos prema stranom u putopisima Miloša Crnjanskog“. U: Šutić, M. (ured.). Miloš Crnjanski, teorijsko-estetički pristup književnom delu, Beograd: Institut za književnost i umetnost, str. 251-257.

„Žrtve u Prvom svjetskom ratu. Žrtve po zemljama“" (3. februar 2015). Wikipedia. Preuzeto 21.06. 2015 sa: http://sh.wikipedia.org/wiki/\%C5\%BDrtve_u_Prvom_svjetskom_ratu

Šulović S. (2014). „Iz dokumenata Arhiva Srbije: Ovako je Austrija objavila rat Srbiji“. Blicmagazin, 23. 02. 2014, br. 6118, str.16-17.

Willius, P. (1997). Learning to Labour: How Working Klass Kids Get Working Class Jobs. Aldershot: Gower 
Sofija M. Košničar

\title{
ASPECTS OF OTHERNESS IN THE EARLY MILOŠ CRNJANSKI'S TRAVEL DIS- COURSE ABOUT BANAT SHWABIANS IN THE LIGHT OF POTESTARY IMAGOLOGY
}

\begin{abstract}
SUMMARY
This paper is focused on potestary imagology aspects in the travel prose of Miloš Crnjanski, a topic related to problems of the life of the Shwabians settled in Banat who, after the First World War, belonged to the Kingdom of Serbs, Croats and Slovenians. War repercussions were in a specific way reflected on the post-war life of the Banat Shwabians, who in the new social context, found themselves in the position of Inner Otherness. The subject of the research has been considered on the grounds of striking travel testimony of Crnjanski [About Banat and People from Banat, and Reports from Vojvodina, from 1923-1925]. It is noticeable that the Crnjanski's perception of the Shwabians is built in the form of an imagem on the counterpoint of an opposed bilateral pair identity / alterity. Thus, Crnjanski's perceptions of his own country, authorities and people are considered in the same way. In the position of identity is a Serbian entity and in the position of alterity is a German [Shwabian] entity. Visualisation brings views onto positive and negative properties of both sides of the opposed pair. With reference to the above, special attention is given to potestary imagology conceptions with an emphasis on communicative aspects of the authorities and their attitudes towards the Shwabian Otherness, as well as the attitude of the Shwabians towards these authorities in a concrete cultural context.

It can be said that Crnjanski is of the opinion that instead of being enclaved in the ethnic Otherness, functioning on the principles of habituation and metis; concerned only with their own interests; apathetic towards other subjects and circumstances in the context - the Banat Shwabians should have been more integrated and actively and constructively involved in resolving post war social and political crisis in the Kingdom. Thus, in the new state, they would have been accepted and less "foreign"and they would have contributed more to the general wellbeing of the new state union. All the time, through indication, Crnjaskishows that this state union "has not succeeded in becoming the accepted new home" to the Banat Shwabians. On such a Shwabian Othernessin the given context, the potestary mechanism of the Kingdom of the Serbs, Croats and Slovenians had obviously given negative response rejecting the Shwabians as a "foreign body" and letting them to the other state about which Crnjanskitestifies impressively in Žombolju na točkovima [To Jimbolia on Wheels].
\end{abstract}

Key Words: potestary imagology/ travel reports by M. Crnjanski / Banat Shwabians / Inner Otherness / metis 